\title{
Neurotrophin Receptor Genes Are Expressed in Distinct Patterns in Developing Dorsal Root Ganglia
}

\author{
Xiaojun Mu, ${ }^{1, a}$ Inmaculada Silos-Santiago, ${ }^{1, a}$ Steven L. Carroll, ${ }^{2}$ and William D. Snider ${ }^{1}$ \\ Departments of 'Neurology and Neurological Surgery (Neurology), and Pathology and Internal Medicine, Washington \\ University Medical School, St. Louis, Missouri 63110
}

All members of the neurotrophin family of neuronal growth factors promote survival and neurite outgrowth of dorsal root ganglion (DRG) neurons in vitro. The trk family of protooncogenes encodes receptors that are now thought to mediate the biological effects of neurotrophins. In order to learn more about the dependence of DRG neurons on neurotrophins in vivo, we have studied mRNA expression of members of the trk family in developing DRGs in embryonic and postnatal rats. We show here that neurotrophin receptors are expressed in thoracic and lumbar DRGs by embryonic day 13 (E13), which is only 24-48 hr after neurogenesis begins in these ganglia. Distinct patterns of expression of $t r k A, t r k B$, and $t r k C$ are readily apparent by $E 15$. At this age, $40 \%$ of thoracic DRG neurons express trkA. In contrast, trkB and trkC are expressed by only $6 \%$ and $8 \%$, respectively, of thoracic DRG neurons. These percentages change little between E15 and postnatal day 1. Although absolute numbers of DRG neurons expressing neurotrophin receptors are greater in lumbar than in thoracic ganglia, the ratios of DRG neurons expressing different members of the trk family are similar in the two regions.

The different trks are expressed by distinct populations of DRG neurons from E15 onward. trkA is expressed predominantly by small neurons with darkly staining cytoplasm. trkB and trkC are expressed by large, lightly staining neurons. Size-frequency histograms show that trkA is expressed by neurons of variable sizes, but particularly by neurons at the smallest end of the spectrum. In contrast, trkC is expressed predominantly by large DRG neurons, including those with the largest soma areas. trkB is expressed by DRG neurons of intermedlate size.

Our results show that a majority of DRG neurons express mRNA for at least one member of the trk protooncogene family. Furthermore, trk expression occurs in a time frame consistent with the idea that trks mediate responses of DRG neurons to neurotrophins that are synthesized in both the periphery and spinal cord at early developmental stages. Finally, different populations of DRG neurons express dif-

\footnotetext{
Received Jan. 8, 1993; revised Mar. 22, 1993; accepted Apr. 7, 1993.

We thank Dr. L Parada for the generous gift of trkA, V. Nguyen for technical assistance, and E. M. Johnson Jr. for comments on the manuscript. This work was supported by NS31768 to W.D.S., Program Project NS17763, and a pilot grant from Amgen.

Correspondence should be addressed to William D. Snider, M.D., Department of Neurology, Box 8111, Washington University School of Medicine, 660 South Euclid Avenue, St. Louis, Missouri 63110.

aShould be considered co-first author.

Copyright (C) 1993 Society for Neuroscience $0270-6474 / 93 / 134029-13 \$ 05.00 / 0$
}

ferent trks. We hypothesize that DRG neurons subserving different functions express different trks, and that trk expression of a particular class of DRG neurons determines its neurotrophin dependence during development.

[Key words: neuronal growth factors, $\operatorname{trk} A, \operatorname{trk} B, \operatorname{trk} C$, dorsal root ganglion neuron classes]

A fundamental advance in the understanding of how growth factors act in the developing nervous system has occurred with the identification of receptors that mediate the biological actions of the neurotrophin family of neuronal growth factors (Klein et al., 1989, 1990, 1991; Martín-Zanca et al., 1990; Lamballe et al., 1991; for a review, see Bothwell, 1991). The identification of these receptors is the first step in understanding how the actions of NGF and other neurotrophins are mediated, and provides a way of tentatively identifying cells that may respond to particular neurotrophins in the nervous system. In vitro, the protein product of the protooncogene trkA binds NGF with high affinity and exhibits tyrosine kinase activity after NGF binding (Kaplan et al., 1991a,b). Similarly, trkB binds and is activated by brain-derived neurotrophic factor (BDNF), and trkC binds and is activated by neurotrophin-3 (NT-3) (Lamballe et al., 1991; Soppet et al., 1991; Squinto et al., 1991). A recent NGF deprivation experiment has demonstrated that dorsal root ganglion (DRG) cells expressing trkA require NGF for survival, and that DRG neurons expressing $t r k \mathrm{~B}$ and $t r k \mathrm{C}$ are $\mathrm{NGF}$ independent. This result shows that the patterns of neurotrophin binding to trks observed in vitro have physiological significance (Carroll et al., 1992). Although some degree of cross-reactivity has been demonstrated in vitro (Berkemeier et al., 1991; CordónCardo et al., 1991; Lamballe et al., 1991; Soppet et al., 1991), whether neurotrophins can activate multiple trks in vivo is not settled (see Ip et al., 1993). Recent surveys have demonstrated that $t r k \mathrm{~B}$ and $t r k \mathrm{C}$ are widely expressed in both PNS and CNS during development and in maturity (Ernfors et al., 1992; Merlio et al., 1992). These studies suggest that neurotrophins have important and widespread roles in regulating neural development and in maintaining functions of neurons in adulthood.

The DRG is an ideal system in which to delineate the functions of the different neurotrophin receptors. In vitro, all neurotrophins promote neurite outgrowth from DRG explants and dissociated cultures (Lindsay et al., 1985; Davies et al., 1986; Leibrock et al., 1989; Hohn et al., 1990; Maisonpierre et al., 1990; Berkemeier et al., 1991). In addition, recent studies (Martín-Zanca et al., 1990; Carroll et al., 1992; Ernfors et al., 1992; Merlio et al., 1992; Schecterson and Bothwell, 1992; Verge et al., 1992) show that neurotrophin receptors are expressed in DRGs in vivo. Furthermore, the biological functions of NGF 
during development in preventing naturally occurring cell death and in the regulation of the synthesis of transmitter enzymes have been well described in DRGs (Kessler and Black, 1980; Otten et al., 1980; Hamburger et al., 1981; Johnson et al., 1986). The extent to which newer neurotrophins, acting through their appropriate receptors, may mediate actions that are similar to or different from those of NGF is unknown.

DRG neurons are an extremely heterogeneous population, consisting of at least 20 functional classes in mammals based on characteristic physiological responses, innervation of characteristic receptors in peripheral tissues, and characteristic patterns of arborization in the spinal cord (for reviews, see Brown, 1981; Willis and Coggeshall, 1991; Perl, 1992). It is highly likely that different neurotrophins have differing effects on these different populations of DRG neurons. In previous work, we have shown that administration of a specific anti-NGF antibody in utero lesions populations of DRG neurons that project to the superficial dorsal horn and express $\operatorname{trkA}$ (Carroll et al., 1992; Ruit et al., 1992). trkB- and trkC-expressing cells that project to more ventral spinal layers are NGF independent. The NGF independence of the $t r k \mathrm{~B}$ - and $t r k \mathrm{C}$-expressing neurons in the DRG suggests that they may be supported by other neurotrophins, such as BDNF, NT-3, or NT-4/5.

Ncurotrophins arc cxpressed in the peripheral and central target fields of DRG neurons during development. The patterns of expression of NGF, BDNF, and NT-3 both in the periphery and the spinal cord have recently been described (Ernfors and Persson, 1991; Schecterson and Bothwell, 1992; see also Davies et al., 1987). Interestingly, these factors are present in different locations in the periphery. For example, NGF is expressed in superficial epidermis, BDNF in deeper layers of developing dermis, and NT-3 in muscle. Of particular interest is that NT-3 is also expressed in the ventral horn of the spinal cord. These findings raise the possibility that DRG cells projecting to these different locations may have different neurotrophin responsiveness. Expression of neurotrophins in DRG target fields is present early in neural development. Expression of NT-3 in spinal cord is first seen on embryonic day 13 (E13) in rat (Ernfors and Persson, 1991), and expression of neurotrophins in spinal cord, skin, and muscle is well established by E11.5 in mouse (Schecterson and Bothwell, 1992). Thus, neurotrophins are expressed in DRG target fields soon after neurogenesis begins in the ganglia.

Two issues are fundamental to delineating the functions of the newly described members of the neurotrophin family in regulating DRG development. The first is whether neurotrophin receptors appear during development in an appropriate time frame to allow DRG neurons to respond to neurotrophins being synthesized in DRG cell target fields. The second is whether different DRG neuron classes express different neurotrophin receptors. In order to address these issues, we have studied the expression of neurotrophin receptor genes in rat DRGs during embryonic and postnatal development.

\section{Materials and Methods}

All experiments were performed on Sprague-Dawley rats. Embryos were studied at E13 and E15. Postnatal animals were studied on postnatal day 1 (PN1) and PN21. E13 was chosen because neurogenesis is still occurring at this age (Lawson et al., 1974; Altman and Bayer, 1984). Animals were studied at E15 because naturally occurring cell death is ongoing at this age in DRGs and E15 is prior to the time central connections are established (Jacobson, 1991; Snider et al., 1992). At PN1, patterns of connectivity in the periphery, spinal cord, and dorsal column nuclei are well established (Smith, 1983; Snider et al., 1992; see Scott, 1992, for a review). By PN21 animals survive independently of the mother, and therefore sensory systems are considered to be relatively mature.

In order to harvest embryos, females were anesthetized at an appropriate stage of pregnancy with a cocktail of ketamine $\mathrm{HCl}$ (Vetalar; 100 $\mathrm{mg} / \mathrm{ml}$ ), xylazine (Rompum; $20 \mathrm{mg} / \mathrm{ml}$ ), and acepromazine maleate (PromAce; $10 \mathrm{mg} / \mathrm{ml}$ ) in a 3:3:1 mixture by volume. Embryos were taken by cesarean section. E13 embryos were fixed by immersion in a fixative solution of $4 \%$ paraformaldehyde in $0.1 \mathrm{~m}$ phosphate buffer (pH 7.2). E13 embryos were then processed intact for paraffin histology. Embryos at E15 and postnatal animals were perfused through the left ventricle with $4 \%$ paraformaldehyde in $0.1 \mathrm{M}$ phosphate buffer. Following perfusion, animals were postfixed in ice-cold $4 \%$ paraformaldehyde overnight. Because of the possibility of significant differences in patterns of expression of neurotrophin receptors, thoracic and lumbar ganglia were studied separately in animals older than E13. Thoracic (T4-T9) and lumbar (L2-L5) DRGs and spinal cords wcre removed from E15 and older animals and processed for paraffin embedding. Sections were cut at $5 \mu \mathrm{m}$ thickness and prepared for in situ hybridization. In situ hybridization was performed with ${ }^{35} \mathrm{~S}$-labeled sense and antisense riboprobes. At least three experiments were performed with each neurotrophin receptor probe at each developmental stage in both the thoracic and lumbar regions.

\section{Preparation of $c R N A$ probes}

(1) trkA. pDM97 (a gift from Dr. Luis Parada) is pGEM-7Zf $(+$ ) with a 464 base pair $(\mathrm{bp})$ insert encoding a portion of the extracellular domain of mouse trkA. In order to synthesize a ${ }^{35}$ S-labeled antisense cRNA probe, pDM97 was linearized with SacI and in vitro transcription with T7 RNA polymerase was carried out in the presence of ${ }^{35} \mathrm{~S}$-labeled UTP (New England Nuclear). A sense cRNA probe was transcribed with SP6 polymerase after linearization with XbaI. After treatment with DNase (10 U), probes were extracted with phenol/chloroform/isoamyl alcohol $(25: 24: 1)$, and then precipitated in cold ethanol with glycogen (Boehringer Mannheim) as a carrier.

(2) trkB. A 0.5 kilobase EcoRI-HincII fragment of pFRK16 (ATCC), which encodes a portion of the extracellular domain of mouse $t r k \mathrm{~B}$, was inserted into the pGEM-3Zf(+) vector (Promega) to generate pMU-1. After linearization with EcoRI, an antisense cRNA probe was transcribed with SP6 RNA polymerase in the presence of ${ }^{35}$ S-labeled UTP. A sense cRNA probe was transcribed with $T 7$ polymerase.

(3) trkC. A 577 bp PCR-generated fragment encoding the extracellular domain of rat $t r k \mathrm{C}$ was cloned into the EcoRV site of pBS-KS(+) (Stratagene), to generate JDM836. After linearization with NotI, an antisense cRNA probe was transcribed with T3 RNA polymerase in the presence of ${ }^{35} S$-labeled UTP. A sense $c R N A$ probe was transcribed with 77 RNA polymerase after linearization with Sall.

\section{In situ hybridization}

Five micrometer paraffin sections of spinal cords with attached DRGs were used in all experiments. The in situ hybridization protocol was modified from two published protocols (Wanaka et al., 1990; Yeh et al., 1991). Slides were deparaffinized in xylene and rehydrated in graded (100-30\%) ethanol solutions. Sections were treated with proteinase $\mathrm{K}$ $(10 \mu \mathrm{g} / \mathrm{ml})$ for $30 \mathrm{~min}$ at $37^{\circ} \mathrm{C}$ and then immersed in triethanolamine buffer containing $0.5 \%$ acetic anhydrate. After dehydration in graded ethanol solutions, sections were hybridized with the appropriate sense and antisense cRNA probes in hybridization buffer containing $50 \%$ formamide, $2 \times$ saline-sodium citrate (SSC), $20 \mathrm{~mm}$ Tris ( $\mathrm{pH} 8.0$ ), $1 \times$ Denhardt's, $1 \mathrm{~mm}$ EDTA, $10 \%$ dextran $\mathrm{SO}_{1}, 500 \mu \mathrm{g} / \mathrm{ml}$ yeast tRNA, $100 \mathrm{~mm}$ dithiothreitol (DTT), and $10 \mathrm{U}$ of RNasin. Hybridization was carried out at $55^{\circ} \mathrm{C}$ for $18 \mathrm{hr}$ in a humidified chamber. After hybridization, sections were washed in $2 \times$ SSC containing $10 \mathrm{~mm}$ DTT at room temperature for $20 \mathrm{~min}$ followed by an additional $20 \mathrm{~min}$ wash in the same solution. After a $5 \mathrm{~min}$ wash in $0.5 \times \mathrm{SSC}$ (containing 10 mM DTT) at room temperature, sections were incubated in $0.1 \times$ SSC containing $10 \mathrm{~mm}$ DTT at $65^{\circ} \mathrm{C}$ for $20 \mathrm{~min}$. Sections were then treated with $20 \mu \mathrm{g} / \mathrm{ml}$ RNase $\mathrm{A}$ in $0.5 \mathrm{M} \mathrm{NaCl}, 10 \mathrm{~mm}$ Tris (pH 8.0), $1 \mathrm{~mm}$ EDTA at $37^{\circ} \mathrm{C}$ for $30 \mathrm{~min}$ followed by a $30 \mathrm{~min}$ wash in the same solution without RNase A. After a 15 min wash in $2 \times \mathrm{SSC}$, sections were then incubated in $0.1 \times \mathrm{SSC}$ at $65^{\circ} \mathrm{C}$ for $30 \mathrm{~min}$ followed by a 20 min wash in $0.1 \times$ SSC at room temperature. Sections were then dehydrated through graded ethanols $(30-100 \%)$ and air dried. 

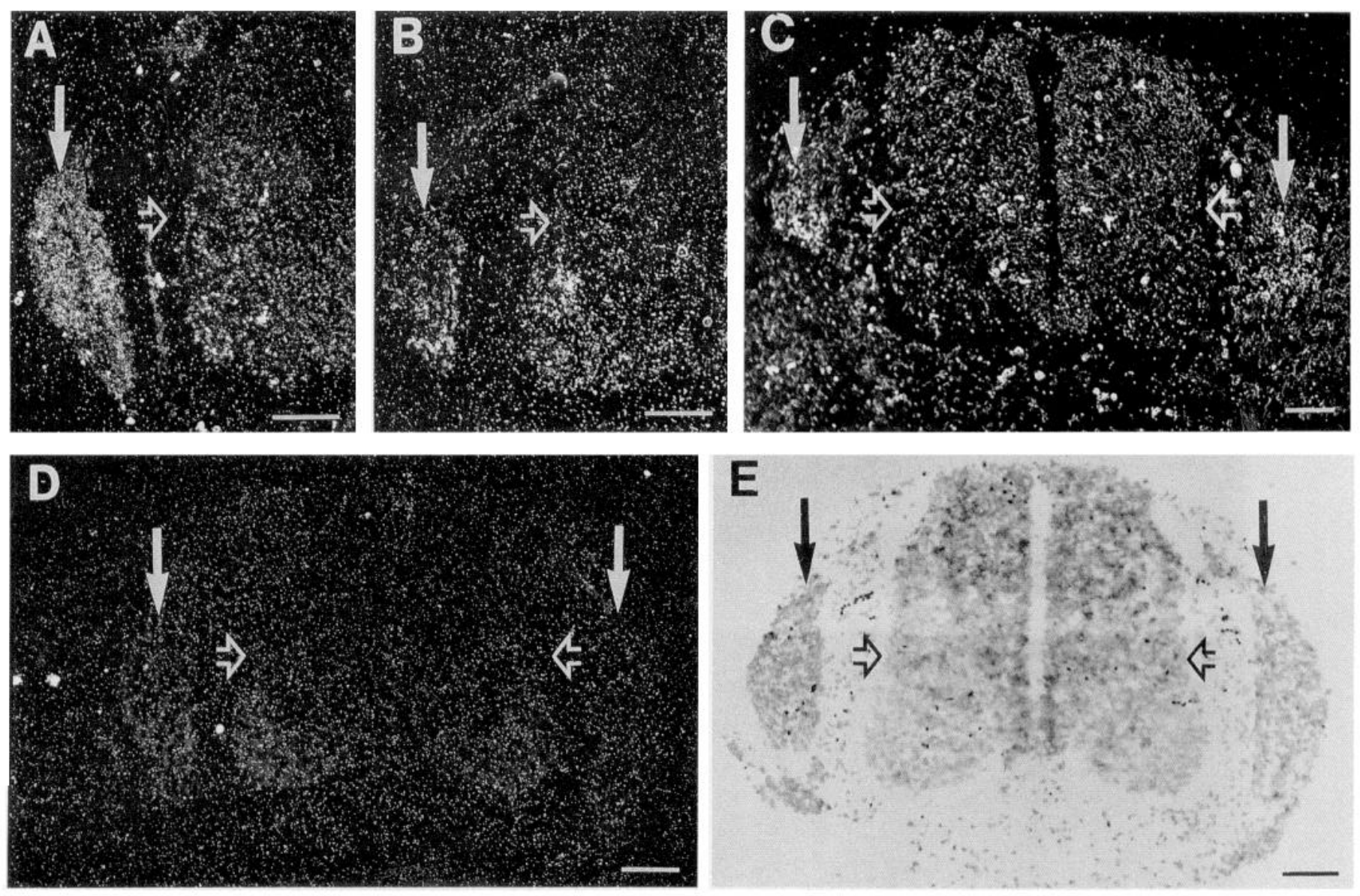

Figure 1. Expression of neurotrophin receptor genes in rat DRGs at E13. A-C, Dark-field photomicrographs of $t r k \mathrm{~A}, t r k \mathrm{~B}$, and $t r k \mathrm{C}$ expression, respectively, at E13, $\operatorname{trkA}, \operatorname{trk\mathrm {B}}$, and $\operatorname{trkC} \mathrm{mRNA}$ can be readily detected in DRGs (solid arrows) even at this early stage. D, Dark-field photomicrograph showing hybridization with a $t r k \mathrm{~B}$ sense mRNA probe. $E$, Bright-field photomicrograph showing the cytoarchitecture of DRGs and spinal cord at E13. Solid arrows denote DRGs, and the borders of the spinal cord are indicated by open arrows in $A-E$. Scale bars: $A-C$, $50 \mu$ m; $D$ and $E, 100 \mu \mathrm{m}$.

\section{Autoradiography}

Slides were exposed to $\mathrm{x}$-ray film (Kodak) for 1-2 d. Signal strength on the $\mathrm{x}$-ray film determined the time of exposure to emulsion. Slides were dipped in Kodak NTB-2 emulsion, which was diluted 1:1 with distilled water and equilibrated at $42^{\circ} \mathrm{C}$. After air drying, the slides were exposed in a desiccator at $4^{\circ} \mathrm{C}$ for $7-15 \mathrm{~d}$. The slides were then developed in Kodak D19 at $15^{\circ} \mathrm{C}$ for $5 \mathrm{~min}$. After counterstaining with hematoxylin and eosin (Sigma), the slides were mounted with Krystalon (Diagnostic Systems, Inc).

\section{Morphometry of trk-expressing neurons in $D R G$}

To determine the number of sensory neurons per section expressing different $t r k$ neurotrophin receptors, cell profiles were viewed and drawn with the aid of a camera lucida at $625 \times$. Only neurons with a nucleus visible in the section were counted and drawn. Glial cells had small, dark-staining nuclei and could be unambiguously identified with the hematoxylin and eosin counterstain. Cells were considered positive for the expression of a neurotrophin receptor mRNA when more than 10 silver grains were detected over the neuronal soma. This number was chosen because hybridization with sense probes invariably resulted in less than five silver grains per cell profile. Percentages of DRG neurons expressing the different neurotrophin receptors were computed from these data.

For determination of cellular cross-sectional areas, profiles of DRG neurons were traced on a digitizing tablet (Summagraphics) interfaced with computer software designed to calculate areas (BIOQUANT, R\&M Biomedics). For each neurotrophin receptor gene at each developmental stage, size-frequency histograms were constructed in both thoracic and lumbar ganglia for all DRG neurons, for neurons expressing the particular trk being studied, and for neurons not expressing that trk. Crosssectional areas of DRG neurons in all of these groups were compared using an unpaired Student's $t$ test.

\section{Results}

\section{Temporal sequence of neurotrophin receptor expression in} DRGs

We first examined the expression of mRNAs encoding different members of the trk family at various developmental stages in rat thoracic and lumbar DRGs. All three trks were clearly expressed in thoracic DRGs by E13, which is approximately 24$48 \mathrm{hr}$ after DRG neurogenesis begins in this region (Altman and Bayer, 1984). Examples of $t r k \mathrm{~A}, t r k \mathrm{~B}$, and $t r k \mathrm{C}$ expression in DRGs at E13 are shown in Figure $1 A-C$ (solid arrows). Examination of ganglia under bright field at high power revealed that only a subset of DRG neurons expressed each trk even at this early stage (see below). By E15, trks were expressed with differing and characteristic patterns within DRGs and spinal cord. $\operatorname{trkA}$ appeared to be diffusely expressed in DRGs (Fig. $2 A$, thick arrows). Expression appeared diffuse because clusters of small DRG neurons express trkA (see below). There was no 

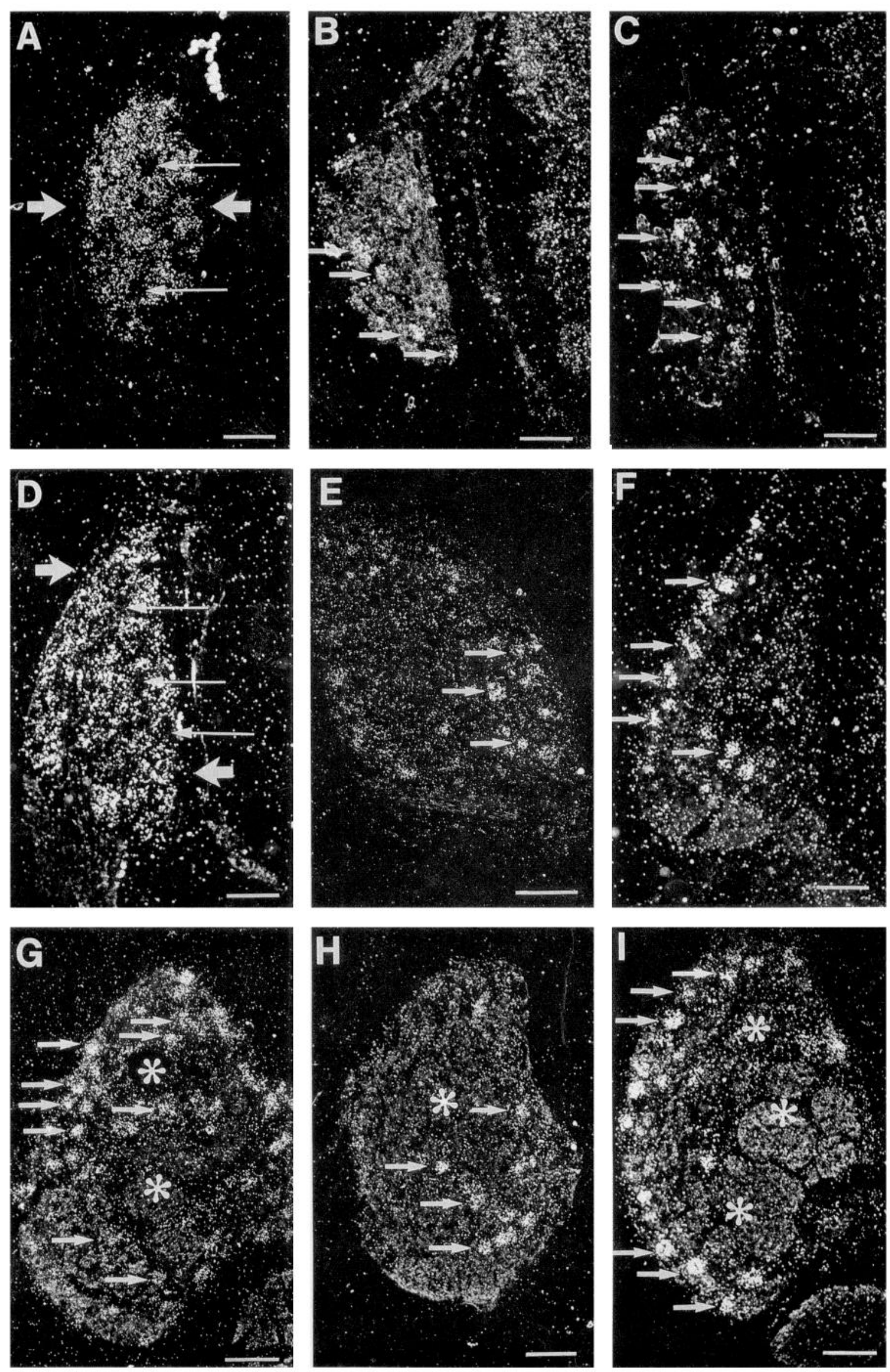
Table 1. Percentages of DRG cells expressing different $t r k s$

\begin{tabular}{lrrrr} 
& E15 & \multicolumn{3}{c}{ PN1 } \\
\cline { 2 - 3 } \cline { 5 - 5 } & Th & L & Th & \multicolumn{1}{c}{ L } \\
\hline $\operatorname{trkA}(\%)$ & 40 & 32 & 46 & 46 \\
$\operatorname{trkB}(\%)$ & 6 & 8 & 6 & 5 \\
$\operatorname{trkC}(\%)$ & 8 & 9 & 10 & 10
\end{tabular}

Th, thoracic ganglia; L, lumbar ganglia. Note that there is little change between $\mathrm{E} 15$ and PN1. Also note that there is virtually no difference between thoracic and lumbar DRGs in these percentages. Values were based on examination of at least 500 cells for each time point and each probe.

trkA expression in the spinal cord (not shown). The localization of $t r k \mathrm{~B}$ mRNA was entirely different. $t r k \mathrm{~B}$ was expressed by a small subpopulation of neurons in DRGs (Fig. $2 B$, arrows), and was expressed diffusely in the spinal cord (not shown). $t r k \mathrm{C}$ message, like $t r k \mathbf{B}$, was expressed intensely by a minority of DRG neurons (Fig. $2 C$, arrows). trkC message was also abundant in the adjaccnt spinal cord (not shown).

The patterns of expression of neurotrophin receptors in DRGs during development are shown in Figure 2. Figure $2 A-C$ shows the expression of $t r k \mathrm{~A}, \operatorname{trk\mathrm {B}}$, and $t r k \mathrm{C}$, respectively, in DRGs at E15. In Figure $2 A$, the borders of the DRG are indicated by the thick arrows. The long arrows indicate regions where trkA is not expressed, demonstrating that not all DRG neurons express mRNA for this receptor. $t r k \mathrm{~B}$ - and $t r k \mathrm{C}$-expressing neurons are indicated by arrows in Figure 2, $B$ and $C$. Expression of the three trks is shown at PN1 in Figure $2 D-F$. Again, in Figure $2 D$, long arrows denote regions of the DRG where mRNA for $t r k \mathrm{~A}$ is not expressed. Arrows in Figure 2, $E$ and $F$, indicate neurons expressing trk $\mathrm{B}$ and $t r k \mathrm{C}$, respectively. Expression of $t r k \mathrm{~s}$ at PN2 1 is shown in Figure $2 G-I$. Arrows denote $t r k$-expressing neurons in all three panels. Asterisks denote regions of the ganglion occupied by fascicles of myelinated and unmyelinated axons that are prominent by this age. Individual ncurons expressing trkA (Fig. $2 G$, arrows) can be resolved at this age because of the increase in neuronal size that has occurred between PN1 and PN21.

It is apparent that the overall pattern of expression of the different $t r k s$ in DRGs changes little during the developmental period analyzed here. Thus, at all stages, $\operatorname{trkA}$ message is widely distributed in DRGs whereas $t r k \mathrm{~B}$ and $t r k \mathrm{C}$ are expressed by a minority of neurons. There is no trkA expression in spinal cord even as late as PN21. In contrast, at each of these developmental stages, $t r k \mathrm{~B}$ and $t r k \mathrm{C}$ are abundantly expressed in spinal cord.

\section{Percentages and locations of DRG neurons expressing different neurotrophin receptors}

Table 1 shows the percentage of DRG neurons expressing the three trks at E15 and PN1. Of note is that $40 \%$ of neurons express $t r k \mathrm{~A}$ in thoracic DRGs and $32 \%$ in lumbar DRGs at
E15

PN1

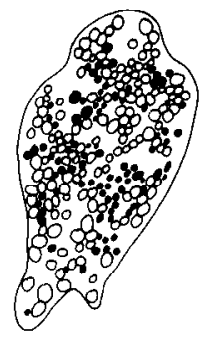

trk A

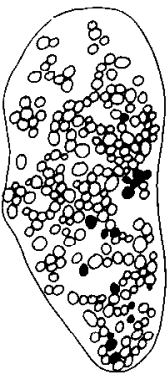

trkB

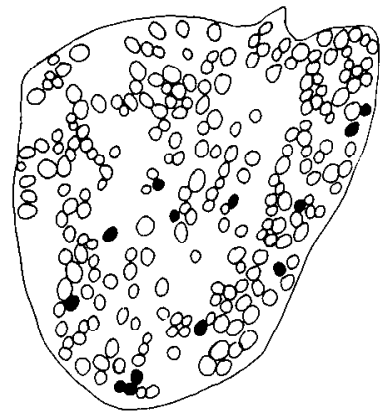

trkC
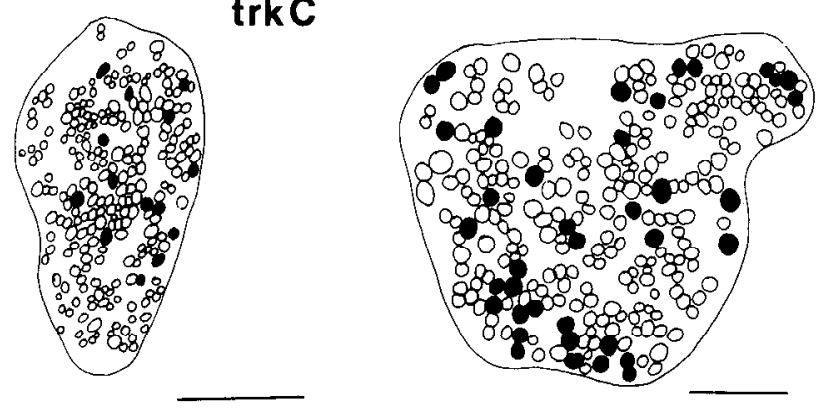

Figure 3. Camera lucida tracings of representative sections of DRG showing the positions of DRG neurons expressing each member of the trk family. The left column shows ganglia from animals at E15, and the right column shows ganglia from animals at PN1. The positions of DRG neurons expressing a particular $t r k$ are denoted by solid profiles, whereas the positions of nonexpressing neurons are denoted by the open profiles. In general, the different trks were not found in specific locations within the ganglia even at early developmental stages. There was a tendency for neurons expressing trkA to cluster in small groups, but these groups were evenly distributed throughout the ganglia. $t r k \mathrm{~B}$ - and $t r k \mathrm{C}$-expressing neurons showed a slight tendency to localize to peripheral regions of the ganglia. Scale bars, $100 \mu \mathrm{m}$.

E15. In contrast, only $8 \%$ and $9 \%$ of DRG neurons in thoracic and lumbar ganglia, respectively, express $t r k \mathrm{C}$, and only $6 \%$ and $8 \%$ of DRG neurons express trkB. The percentage of neurons expressing the different $t r k$ s changed little between E15 and PN1. At PN1, in both thoracic and lumbar DKGs, $46 \%$ of

Figure 2. Higher-power dark-field views of neurotrophin receptor gene expression in DRGs during embryonic and postnatal development: E15 $(A-C)$, PN1 $(D-F)$, and PN21 $(G-I)$. Left column, trkA; middle column, trkB; right column, trkC. In $A$ (E15) and $D$ (PN1), the DRG is denoted by thick arrows. Expression of $t r k \mathrm{~A}$ appears diffuse at this magnification because $t r k \mathrm{~A}$ is expressed by small cells within the ganglion, many of which are clustered. Long arrows denote regions of the ganglion containing cells that do not express $t r k$ A. By PN21 $(G)$, individual trkA-expressing cells can be resolved and are denoted by arrows. As early as E15 $(B)$, the pattern of $t r k \mathrm{~B}$ expression looks quite different from that of trkA. trkB is intensely expressed a small minority of DRG cells (arrows). The pattern of $t r k \mathrm{~B}$ expression is similar at PN1 $(E)$ and PN2l $(H)$. Expression of trkC at E15 $(C)$, PN1 $(F)$, and PN21 $(I)$ is similar to the pattern for trkB except that $t r k \mathrm{C}$ is expressed by a slightly higher percentage of cells. In $G-I$ the asterisks indicate regions of the ganglion occupied by axons. $A, C, F$, and $H$ are thoracic DRGs, and $B, D, E, G$, and $I$ are lumbar DRGs. Scale bars: $A-C, 50 \mu \mathrm{m} ; D-I, 100 \mu \mathrm{m}$. 

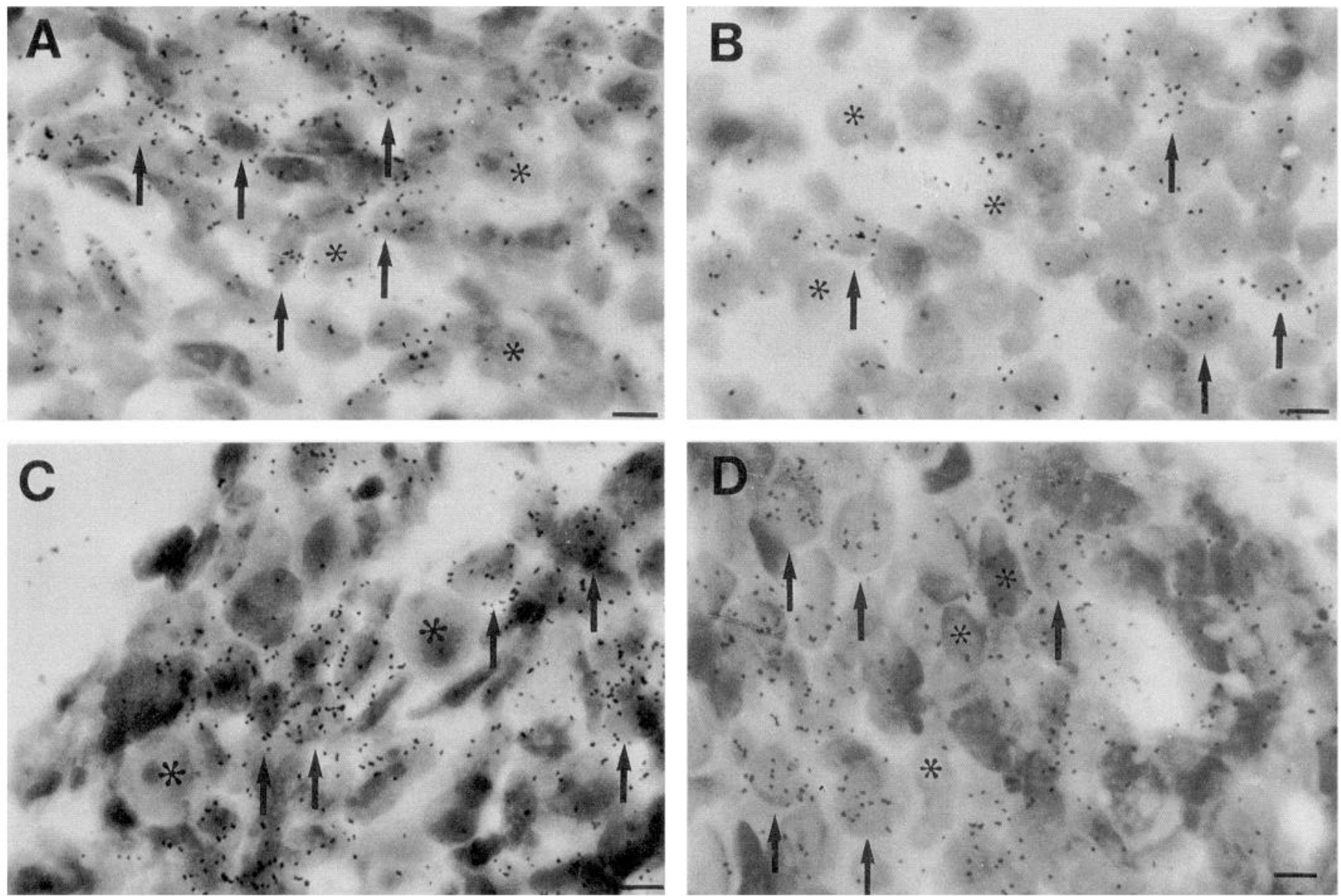

Figure 4. High-power bright-field photomicrographs of neurotrophin receptor gene expression by DRG cells at E13 (A, B) and E15 (C, D). Left column, trkA; right column, trkC. In $A$ and $C$, representative $\operatorname{trkA}$-expressing neurons are indicated by arrows. Representative trkA-negative neurons are marked by asterisks over their nuclei. In $B$ and $D$, typical $t r k C$-expressing neurons are marked by arrows, and trkC-negative neurons, by asterisks. By E13, expression of $t r k \mathrm{~A}$ and $t r k \mathrm{C}$ is already restricted to subsets of DRG neurons. By E15, it is readily apparent that $t r k \mathrm{~A}$ is expressed by small DRG neurons whereas $t r k C$ is expressed by large DRG neurons (compare $C$ and $D$ ). Scale bars, $6.5 \mu \mathrm{m}$.

Table 2. Soma areas of DRG neurons expressing different $t r k s$

\begin{tabular}{|c|c|c|c|c|c|c|}
\hline & \multicolumn{2}{|l|}{ E15 } & \multicolumn{2}{|l|}{ PN1 } & \multicolumn{2}{|l|}{ PN21 } \\
\hline & $\mathrm{Th}$ & $\mathrm{L}$ & Th & $\mathrm{L}$ & Th & $\mathrm{L}$ \\
\hline DRG & $58 \pm 0.9$ & $56 \pm 0.7$ & $119 \pm 1.9$ & $226 \pm 4.2$ & $469 \pm 7.1$ & $529 \pm 9.3$ \\
\hline trkA & $50 \pm 1.0 \ddagger$ & $43 \pm 0.9 \ddagger$ & $98 \pm 2.1 \mp$ & $192 \pm 4.6 \ddagger$ & $420 \pm 10 \ddagger$ & $454 \pm 12 \ddagger$ \\
\hline non-trkA & $64 \pm 1.2$ & $62 \pm 0.9$ & $136 \pm 2.6$ & $257 \pm 6.1$ & $487 \pm 8.8$ & $561 \pm 12$ \\
\hline DRG & $56 \pm 0.6$ & $60 \pm 0.7$ & $207 \pm 4.0$ & $223 \pm 2.5$ & $450 \pm 9.0$ & $438 \pm 8.5$ \\
\hline $\operatorname{trk\mathrm {B}}$ & $66 \pm 2.5^{*}$ & $72 \pm 2.2^{*}$ & $250 \pm 13^{* *}$ & $269 \pm 11^{* *}$ & $590 \pm 28 \ddagger$ & $515 \pm 20 \dagger$ \\
\hline non-trkB & $56 \pm 0.7$ & $59 \pm 0.8$ & $204 \pm 4.2$ & $221 \pm 2.6$ & $440 \pm 9.0$ & $429 \pm 9.1$ \\
\hline DRG & $52 \pm 0.9$ & $56 \pm 0.9$ & $173 \pm 1.5$ & $174 \pm 2.8$ & $410 \pm 7.0$ & $576 \pm 10$ \\
\hline $\operatorname{trkC}$ & $87 \pm 4.2 \ddagger$ & $92 \pm 3.4 \ddagger$ & $259 \pm 5.8^{* * *}$ & $252 \pm 8.8 \ddagger$ & $719 \pm 22 \ddagger$ & $883 \pm 22 \ddagger$ \\
\hline non-trkC & $49 \pm 0.8$ & $53 \pm 0.7$ & $163 \pm 1.3$ & $159 \pm 2.4$ & $353 \pm 5.4$ & $487 \pm 8.7$ \\
\hline
\end{tabular}

For each age data from at least 500 cells from three sections of thoracic (Th) and lumbar (L) ganglia are shown. For each $t r k$ the mean soma area \pm SE of three groups is shown: DRG denotes the mean soma area of all neurons within the ganglion, trk denotes the mean soma area neurons expressing the particular trk shown, and non-trk denotes neurons that do not express that particular trk.

* Values not significantly different from total DRG neuronal population ( $p>0.05$ by Student's $t$ test).

** Values significantly different from total DRG neuronal population ( $p<0.02$ by Student's $t$ test).

† Values significantly different from total DRG neuronal population ( $p<0.005$ by Student's $t$ test).

‡ Values significantly different from total DRG neuronal population ( $p<0.001$ by Student's $t$ test). 
neurons express $t r k \mathrm{~A}, 10 \%$ of neurons express $t r k \mathrm{C}$, and about $6 \%$ of neurons express $t r k \mathrm{~B}$. Although the absolute number of neurons expressing all of the trks was greater in the lumbar DRGs, we found little difference in percentages of neurons expressing different $t r k s$ between thoracic and lumbar DRGs. The situation at PN21 is more complex in that superficial versus deeper regions of the ganglia seem to vary slightly in percentages of cells expressing different $t r k s$. This issue is currently under further study.

We next examined the positions of cells expressing different neurotrophin receptor genes at E15 and PN1 by making detailed camera lucida tracings of DRGs and noting the position of neurons expressing different $t r k s$. These tracings are shown in Figure 3. The positions of DRG neurons expressing a particular trk are denoted by solid profiles, whereas the positions of nonexpressing neurons are denoted by the open profiles. For each of the $t r k$ populations, labeled neurons were distributed throughout the ganglion. trkA-expressing neurons were sometimes clustered in small groups, but these clusters were evenly distributed throughout all regions of the DRG. $t r k \mathrm{~B}$ - and $t r k \mathrm{C}$-expressing neurons were also distributed throughout the DRG, although there was a tendency for these neurons to be located toward the periphery. There were no discernable difference in these patterns between E15 and PN1.

\section{Morphological characteristics of DRG neurons expressing different neurotrophin receptors}

It was apparent on high-power bright-field examination of our material that particular neurotrophin receptors were expressed by DRG neurons having different morphological characteristics. By E13, it was already apparent that expression of each trk was restricted to a subset of DRG neurons. In Figure $4, A$ and $B$ show patterns of expression of $t r k \mathrm{~A}$ and $t r k \mathrm{C}$, respectively, at E13. DRG neurons expressing a particular trk are denoted by arrows, whereas nonexpressing neurons are denoted by an asterisk over the nucleus. Clearly, many DRG neurons do not express trkA (Fig. 4A, asterisks) at this age. Similarly, many DRG neurons do not express $t r k \mathrm{C}$ at E13 (Fig. $4 B$, asterisks). trkB also was expressed by only a subset of DRG neurons at E13 (data not shown). Figure 4, $C$ and $D$, shows $t r k \mathrm{~A}$ and $t r k \mathrm{C}$ expression, respectively, at E15. By this age, it is apparent that DRG neurons expressing trkA (Fig. $4 C$, arrows) are smaller than non-trkA-expressing neurons (Fig. $4 C$, asterisks). In contrast, DRG neurons expressing trkC (Fig. $4 D$, arrows) are larger than non- $t r k \mathrm{C}$-expressing neurons (Fig. $4 D$, asterisks). $\iota r k$ B-expressing neurons were of intermediate size (data not shown).

In mature mammals, DRG neurons can be divided on morphological grounds into two categories: small, darkly staining cells and large, lightly staining cells (see Lawson, 1992, for a review). Examination of our material at PN21 revealed that neurotrophin receptor expression was segregated according to cell size and staining characteristics. For example, in Figure 5 it is apparent that the neurons expressing $\operatorname{trkA}$ (Fig. $5 A, B$, arrows; $5 C$, dots) are, in general, smaller than neurons that do not express $\operatorname{trkA}$ (Fig. $5 A-C$, asterisks) and also are smaller than the neurons that express $t r k \mathrm{C}$ (Fig. $5 G, H$, arrows; $5 I$, dots). In contrast, DRG neurons that express $t r k \mathrm{C}$ (Fig. $5 G, H$, arrows; $5 I$, dots) are larger than non-trkC-expressing neurons (Fig. $5 G-$ $I$, asterisks) and also clearly larger than neurons that express trkA (Fig. 5A,B, arrows; $5 C$, dots). Neurons expressing trk $\mathrm{B}$ are of intermediate size (Fig. $5 D, E$, arrows; $5 F$, dots). In general, neurons expressing $t r k \mathrm{C}$ and $t r k \mathrm{~B}$ were large with lightly stained cytoplasm, whereas neurons expressing trkA were small with more darkly stained cytoplasm.

This qualitative impression of size differences was confirmed by the construction of size-frequency histograms (Fig. 6). For this work over 500 neuronal profiles in lumbar DRGs for each ncurotrophin receptor at cach devclopmental stage were assessed. The distributions of soma areas of the neurons labeled by the indicated neurotrophin receptor probe are rendered by the open bars in the histograms. The distributions of soma areas from nonlabeled neurons are shown by the solid bars. Although there is overlap, it is apparent at each developmental stage that trkA-expressing neurons (top row) are smaller than non-trkAexpressing neurons. Furthermore, at PN1 and PN21, virtually all of the DRG neurons with the smallest cross-sectional areas are $t r k \mathrm{~A}$ positive. In contrast, trkC-expressing neurons (bottom row) are larger than non-trkC-expressing neurons at every developmental stage. It is also clear that $t r k \mathrm{C}$-expressing neurons are the largest DRG neurons. Finally, trkB-expressing neurons (middle row) occupy an intermediate range. None of the smallest and few of the largest $\mathrm{DKG}$ neurons express $t r k \mathrm{~B}$. These differences in distributions of soma areas of DRG neurons expressing the different ncurotrophin receptors were present by E15 and persisted throughout development. Size-frequency histograms constructed from soma areas of neurons in thoracic DRGs (not shown) were similar to those shown for lumbar DRGs in Figure 6.

In Table 2 are shown mean soma areas of all DRG neurons (DRG), DRG neurons expressing a particular $t r k$ (trk), and neurons not expressing that $t r k$ (non-trk) at different developmental stages in thoracic ( $\mathrm{Th}$ ) and lumbar (L) ganglia. At every age in both thoracic and lumbar ganglia, the mean soma area of $t r k \mathrm{~A}$ expressing cells was significantly smaller than the mean of nontrkA-expressing neurons and the mean of all neurons in the DRG. In contrast, mean soma areas of $t r k C$-expressing DRG neurons were larger than those of non-trkC-expressing cells as well as those of all DRG neurons. trkB-expressing DRG neurons also had significantly larger soma areas than non-trkB cells at cvery age and were significantly larger than all DRG neurons after E15.

\section{Discussion}

\section{Neurotrophin receptors are expressed early in $D R G$}

development

In this study we have shown that genes for all three $t r k$ s are expressed in rat DRGs at an early stage of development. Thus, expression of $t r k s$ is readily apparent by $\mathrm{E} 13$, which is only 24$48 \mathrm{hr}$ after neurogenesis begins (Lawson et al., 1974; Altman and Bayer, 1984). Our preliminary observations suggest that all three $t r k s$ are expressed in DRGs even earlier, at E12 (X.-J. Mu, I. Silos-Santiago, W. D. Snider, unpublished observations). We have not yet determined the earliest age at which expression appears. The function of this early expression of neurotrophin receptors by DRG cells is unknown. Studies using quail ncural crest primary cultures have suggested that BDNF may influence differentiation of pluripotent neural crest cells along the primary sensory neuron lineage (Sieber-Blum, 1991). It is possible that $D R G$ cells at E12 and E13 may require neurotrophins for differentiation into different functional classes or for survival prior to gaining access to factors from their targets (Wright et al., 1992; Wyatt et al, 1992). We could not determine the percentages of DRG cells that expressed different trks at E13. 


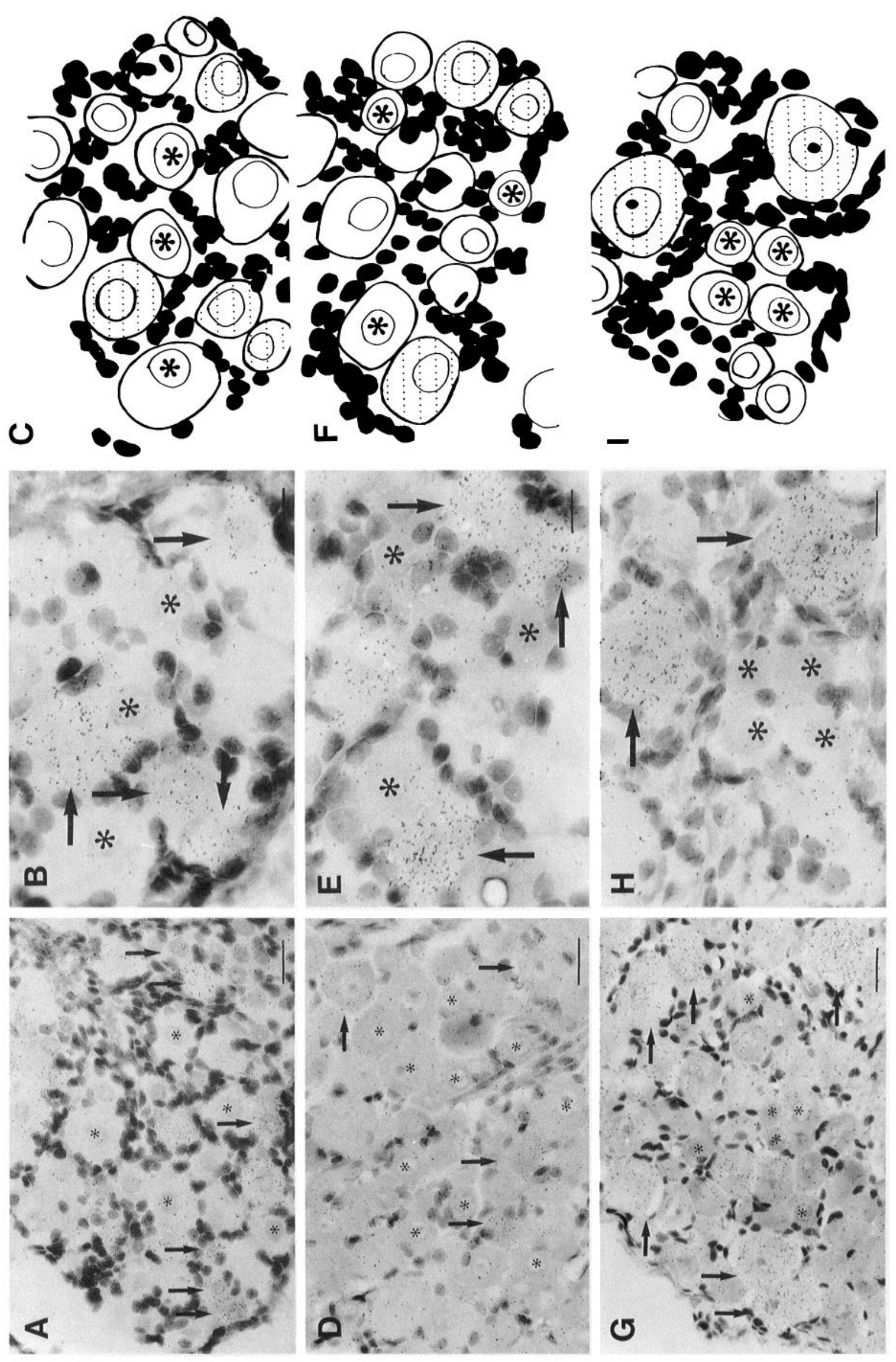

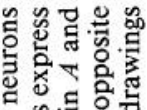

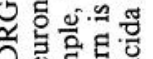

의

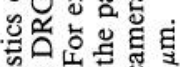

हैं

.

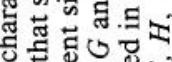

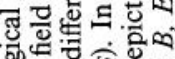

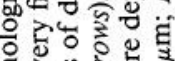

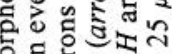

品解

.

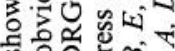

s.t.

.7.

政

\$心

合

원

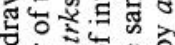

岁菏

हี

和部

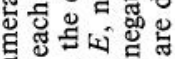

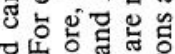

实的

它可.

o

0 ㄴ.

家觉

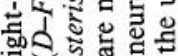

ธึ

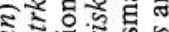

जी

- T

ธัँ

ह

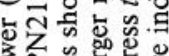

织哭哥产

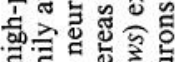
च떤 त्र人 ₹

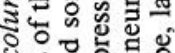
s。 要

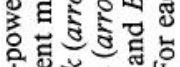

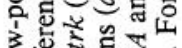

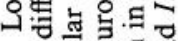
i. 웅

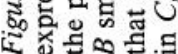


Therefore, we do not yet know whether DRG cells at early stages express multiple trks (see also Ernfors et al., 1992).

By $E 15$, neurotrophin receptor genes are expressed in distinct patterns in DRGs (see below). These patterns of neurotrophin receptor gene expression in DRGs appear to change little between E15 and maturity. Thus, percentages and morphological characteristics of DRG neurons expressing different members of the trk family were stable between E15 and PN21. Assuming that expression of a particular trk determines neurotrophin dependence (see Carroll et al., 1992), our findings suggest that neurotrophin requirements of DRG neurons are established by E15 and do not undergo major shifts subsequently. It should be emphasized, however, that a stable pattern of $t r k$ expression does not necessarily imply regulation by a single neurotrophin, as work in vitro raises the possibility that some neurotrophins may activate multiple trks (Berkemeier et al., 1991; CordónCardo et al., 1991; Soppet et al., 1991; Squinto et al., 1991; but see Ip et al., 1993).

It is important to relate the pattern of trk expression in DRGs we describe here to the known information about neurotrophin synthesis in the peripheral and central target fields of DRG neurons. It has been established that NGF, BDNF, and NT-3 are all synthesized in some peripheral targets of DRG cells by E11.5 in mouse (Schecterson and Bothwell, 1992). Furthermore, NT-3 is synthesized in the ventral horn of the spinal cord starting at E13 in rat (Ernfors and Persson, 1991). Finally, BDNF and NT-3 are synthesized locally within DRGs by E13 in rat and by E15 in mouse (Ernfors and Persson, 1991; Ernfors et al., 1992; Schecterson and Bothwell, 1992). Thus, our demonstration that $t r k$ genes are expressed by E13 in rat DRGs suggests that DRG neurons are capable of responding to neurotrophins that are synthesized in their peripheral and central target fields as well as locally at early developmental stages. These observations thus support the idea that BDNF and NT-3, as well as NGF, are important determinants of DRG development in vivo. Many important aspects of DRG ncuronal development, such as formation of laminar-specific connections in spinal cord, innervation of characteristic end organs in the periphery, development of transmitter phenotype, and naturally occurring cell death, occur well after E13 (Fitzgerald, 1967, 1987; Hamburger et al., 1981; Smith, 1983; Johnson et al., 1986; Davies et al., 1987; Reynolds et al., 1991; Ruit et al., 1992; Snider et al., 1992). Therefore, the observation that all three trks are expressed in DRGs by E1 3 suggests the potential for neurotrophins to regulate these developmental events.

A caveat in interpreting our results is that we have used probes that code for regions of the extracellular domains of these neurotrophin receptors. Recently, forms of $t r k \mathrm{~B}$ that lack the intracellular tyrosine kinase domain have been described (Klein et al., 1990, Middlemas et al., 1991). Thus, for example, ependymal cells lining ventricular surfaces in the CNS express a $t r k \mathrm{~B}$ with no tyrosine kinase motif (Klein et al., 1990). Furthermore, in certain regions of the nervous system, the ratios of tyrosine kinase $^{(+)}$versus tyrosine kinase $^{(-)}$forms of $t r k$ s change markedly during development (Allendoerfer et al., 1992). Whether any of the expression we have observed in developing DRGs is due to neurotrophin receptors lacking tyrosine kinase domains remains to be determined.

\section{Distinct patterns of neurotrophin receptor gene expression in developing DRGs}

A second finding of this study is that neurotrophin receptor genes are expressed in rat DRGs in distinct patterns. We find that the different members of the trk family are expressed by different percentages of DRG neurons, that there are differences in the morphological characteristics of the neurons expressing different $t r k s$, and that there are differences in size-frequency histograms of DRG neurons expressing the different $t r k s$.

trkA is clearly the member of the trk family expressed most abundantly in developing DRGs. In this study, $32-46 \%$ of DRG neurons were shown to express trkA depending on the developmental stage and location of the ganglion studied. These percentages correspond well with the result of a previous study of trkA expression and high-affinity NGF binding in adult rat lumbar DRGs by Verge et al. (1992). In that study, approximately $40 \%$ of DRG neurons expressed $t r k A$ and bound NGF with high affinity. Despite this close agreement, there is a strong possibility that both of these studies have underestimated the true number of trkA-expressing cells in rat DRGs. These percentages for trkA-expressing neurons are at odds with percentages of DRG neuron loss caused by immune deprivation of NGF. Such studies in rats and guinea pigs have shown that $70-85 \%$ of DRG neurons are lost in embryos deprived of NGF by autoimmunity or passive transfer of antibodies (Gorin and Johnson, 1979; Johnson et al., 1980; Ruit et al., 1992). Since DRG neurons killed by NGF deprivation are now known to express $\operatorname{trkA}$ (Carroll et al., 1992), 70-85\% of DRG neurons should express mRNA for this receptor.

There are several technical reasons why percentages of DRG neurons expressing neurotrophin receptor genes might have been underestimated in our study. (1) In order to obtain optimal cellular morphology, we performed in situ hybridizations on paraffin sections. Although we have not tested the issue systematically in our own studies, it has been suggested that in situ hybridization may be less sensitive in paraffin than in frozen material (Tecott et al., 1987). (2) We established a specific number of grains per cell profile as an objective criterion to consider a cell positive for receptor gene expression. Some DRG neurons that actually express mRNA for a member of the trk family might not have met this criterion because of lack of probe sensitivity or low levels of gene expression. (3) Cells on the surface of the section are far more likely to be hybridized than cells in the middle or bottom of the section. These middle and bottom cells were counted in the number of cell profiles per section given here, and many of these may not have had an optimal opportunity for hybridization. Therefore, we conclude that the determination of the absolute numbers and percentages of DRG neurons expressing members of the trk family will require further investigation. However, since we used the same methodology to compute percentages of positive cells for all three probes, the ratios of DRG neurons expressing different neurotrophin receptor genes presented here are likely to be accurate. In support of this idea, these ratios are very similar to those obtained in a previous study that employed frozen rather than paraffin sections (Carroll et al., 1992). Interestingly, If all DRG cells expressed a member of the $t r k$ family, and the ratios of DRG neurons expressing different trks were as given here, then NGF deprivation should lesion approximately $75 \%$ of DRG neurons. This degree of DRG cell loss would be in close agreement with the published values (Gorin and Johnson, 1979; Johnson et al., 1980; Ruit et al., 1992).

Our results are in conflict with those of a previous study that suggested that all DRG neurons express trkA (Schecterson and Bothwell, 1992). We are confident that our conclusion that trkA is not expressed by all DRG neurons is correct for three reasons. (1) Even if observations were confined to cells on the surface of 

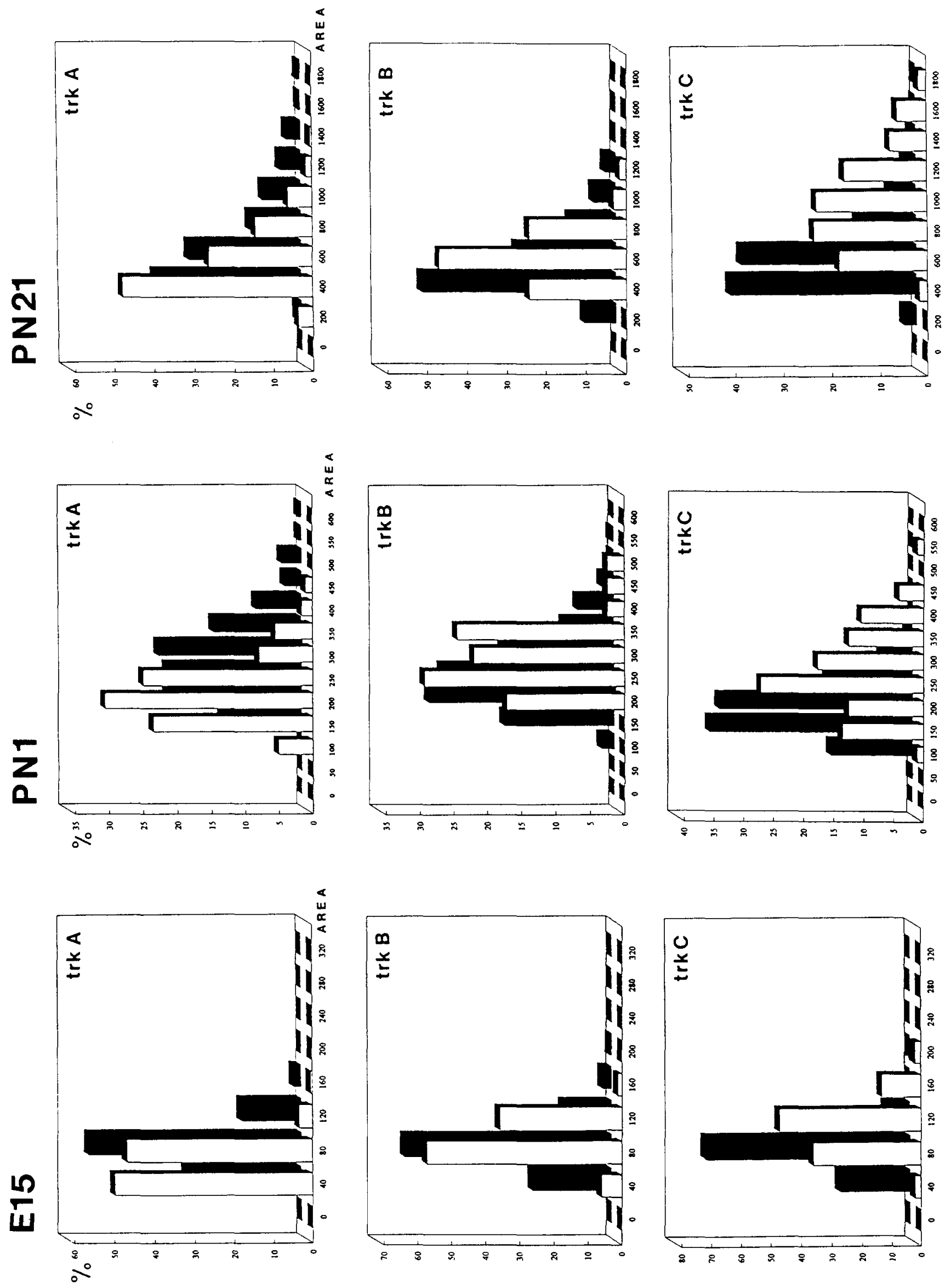
the section and if the criteria for positivity were relaxed to include neurons that had only five grains in a cell profile (data not shown), there were still many neurons in every DRG section to which our trkA probe did not hybridize. (2) trkA-expressing neurons in our study had different sizes and morphological characteristics than did non-trkA-expressing DRG neurons. This observation supports our contention that trkA expression may be restricted to subsets of neurons within the DRG. (3) Finally, in a previous study we have shown that DRG neurons expressing different $t r k$ s differ in their sensitivity to NGF (Carroll et al., 1992). DRG neurons expressing trkA are killed by NGF deprivation in utero, whereas DRG neurons expressing trkB and trkC are NGF independent. If every neuron in the DRG expressed trkA, then trkA should have been detected in the DRG neurons that survived NGF deprivation.

Our results support the idea that DRG neurons belonging to different functional classes express different members of the $t r k$ family. In this study we have shown that DRG neurons expressing different trks have different morphological characteristics. DRG neurons expressing trkA are mainly small neurons with dark cytoplasm. These may correspond to the small, dark neurons in DRGs long recognized on the basis of morphological observations (see Willis and Coggeshall; 1991 and Lawson, 1992, for reviews). In contrast, $t r k \mathrm{~B}$ and $t r k \mathrm{C}$ are expressed by large neurons with abundant cytoplasm and large, pale nuclei. These may correspond to the large, light neurons described in previous anatomical studies (for reviews, see Willis and Coggeshall, 1991; Lawson, 1992). Furthermore, size-frequency histograms of DRG neurons expressing different trks are markedly different. DRG neurons expressing $t r k \mathrm{~A}$ are the smallest cells in the DRG and have mean soma areas significantly smaller than non-trkA neurons. The largest DRG neurons do not express $t r k \mathrm{~A}$. In contrast, trkC is expressed by the largest DRG neurons, and trkC-expressing cells have much larger soma areas than non- $t r k \mathrm{C}$-expressing cells. trkC is not expressed by the smallest DRG neurons. DRG neurons expressing $t r k \mathrm{~B}$ are of intermediate size. None of the smallest DRG neurons express $t r k \mathrm{~B}$ and $t r k \mathrm{~B}$ expressing neurons make up a small minority of the very largest DRG neurons. This segregation of neurotrophin receptor genes according to cell size is present by E15 and is stable throughout development. It is important to point out that cell size is not an absolute correlate of function (see below). However, in general, DRG neurons with unmyelinated or lightly myelinated axons that subserve pain and temperature have smaller somata than DRG neurons that have heavily myelinated axons and subserve proprioceptive functions (Lawson and Waddell, 1991; see Lawson, 1992, for a review).

It is possible, based on the work presented here and in previous studies, tentatively to correlate neurotrophin receptor gene expression with the functional class of DRG neurons. The small, dark DRG neurons, shown to express $t r k \mathrm{~A}$ in the present study, include distinct and overlapping neuronal populations that express substance $\mathbf{P}$ (Hökfelt et al., 1975; McCarthy and Lawson, 1989), calcitonin gene-related peptide (CGRP; Wiesenfeld-Hallin et al., 1984; Skofitsch and Jacobwitz, 1985; McNeil et al.,
1989), fluoride-resistant acid phosphatase (FRAP; KnyiharCsillik and Csillik, 1981; Nagy and Hunt, 1982; Silverman and Kruger, 1988), and a cell adhesion molecule, E-cadherin (Shimamura et al., 1992). Furthermore, some of these neurons are labeled by lectins such as PNA and GSA I-B4 (Streit et al., 1985; Silverman and Kruger, 1988) and antibodies to certain oligosaccharides, particularly A5, LA4, and 2C5 (Jessell and Dodd, 1986; see Lawson, 1992, for a review). Substance P, CGRP, FRAP, LA4, 2C5, GSA I-B4, and E-cadherin are all found in laminae I and II of the dorsal horn, consistent with a role for DRG cells that express these molecules in subserving pain and thermal receptive functions (see Hunt et al., 1992, for a review). The small, dark DRG neurons are also preferentially sensitive to capsaicin, which lesions nociceptive afferents (see Lawson, 1992, for a review).

It is now established that DRG neurons that express trkA require NGF for survival in vivo (Carroll et al., 1992). That NGF supports DRG neurons that subserve nociception is suggested by studies showing that NGF-deprived embryos do not feel pain in the neonatal period (Johnson et al., 1980), that NGFsensitive DRG neurons project to laminae I and II of the dorsal horn (Ruit et al., 1992), and that myelinated nociceptors are depleted by neonatal NGF deprivation (Ritter et al., 1991; Lewin et al., 1992). Finally, it has recently been demonstrated that NGF mRNA is expressed predominantly in superficial layers of developing skin (Schecterson and Bothwell, 1992), consistent with an ability to support nociceptive and thermoreceptive afferents. On the basis of all of these observations, we suggest that DRG neurons that express trkA subserve pain and thermal sensation.

In contrast, DRG neurons with larger soma areas, shown to express $t r k \mathrm{~B}$ and $t r k \mathrm{C}$ in this study, are known to be $\mathrm{NGF}$ independent (Gorin and Johnson, 1979; Johnson et al., 1983; Miyata et al., 1986; Carroll et al., 1992; Ruit et al., 1992). NGFindependent neurons project to laminae III-VI in the dorsal horn and to the ventral horn, the spinal target fields of lowthreshold mechanoreceptors, and proprioceptors (Ruit et al., 1992). It has recently been demonstrated that anti-NGF has no effect on the survival or physiological properties of hair follicle and other cutaneous $A \beta$ afferents (Lewin et al., 1992), further suggesting that many classes of low-threshold mechanoreceptors may be NGF independent. Another observation consistent with this idea is that BDNF is expressed in deeper layers of skin than NGF in a logical location to support low-threshold mechanoreceptors such as hair follicle afferents (Schecterson and Bothwell, 1992). NT-3 is expressed in both muscle and the motor pool of the spinal cord and is therefore available in both the peripheral and central target fields of group Ia DRG neurons that project to muscle spindles and have monosynaptic contact with motor neurons. Thus, at least some DRG neurons that express $t r k \mathrm{C}$ are likely to be proprioceptors. In support of this idea, a recent study has shown that large DRG neurons in chick that project to muscle require NT-3 for survival in vitro (HoryLee et al., 1993). Taken together, all of these observations suggest that $t r k \mathrm{~B}$ - and $t r k \mathrm{C}$-expressing neurons may subserve tactile

Figure 6. Size-frequency histograms of DRG neurons in lumbar ganglia expressing different members of the trk family during development. For each histogram percentages of trk-expressing neurons having a particular soma area are indicated by the open bars. The solid bars indicate the frequencies of soma areas of DRG neurons that do not express the particular $t r k$ being displayed. Soma areas are in $\mu \mathrm{m}^{2}$. At every age, $t r k \mathrm{~A}$ expressing neurons (top row) have smaller soma areas than non-trkA-expressing neurons. In contrast, trkC-expressing neurons (bottom row) have soma areas that are larger than non-trkC-expressing neurons. The soma areas of $t r k \mathrm{~B}$-expressing neurons (middle row) are intermediate. 
and proprioceptive functions. More specifically, it is reasonable to hypothesize that $t r k \mathrm{C}$-expressing neurons subserve proprioceptive functions whereas $t r k \mathrm{~B}$-expressing neurons may be predominantly low-threshold mechanoreceptors.

A number of questions remain unanswered by this study. (1) Do all DRG neurons express a member of the trk family? The percentages in this study suggest that there may be a large population of non-trk-expressing cells in mammalian DRG (see also Verge et al., 1992). However, for the reasons outlined above we feel it is premature to draw such a conclusion at present. It should also be noted that additional members of the $t r k$ family may exist that have not yet been characterized. (2) Do DRG neurons express a single or multiple nembers of the trk family? Our findings that different $t r k s$ are expressed in cells with different morphological characteristics (the present study) and that immune deprivation of NGF kills the $t r k \mathrm{~A}$ population but spares the populations expressing trk $\mathrm{B}$ and $t r k \mathrm{C}$ (Carroll et al., 1992) suggest expression of a single trk by DRG neurons. However, neither of these observations proves that DRG neurons do not express multiple $t r k s$. Indeed, both NGF and BDNF are capable of supporting the majority of chick DRG neurons in vitro, suggesting the possibility that some DRG neurons express both trkA and $t r k \mathrm{~B}$ (Lindsay et al., 1985; Davies et al., 1986). Furthermore, in the CNS it is apparent that many classes of neurons express both $t r k \mathrm{~B}$ and $t r k \mathrm{C}$. Thus, the issue of whether DRG neurons express multiple $t r k s$ will require further investigation. (3) What are the functions of DRG neurons expressing different members of the trk family? The work presented here, although highly suggestive, is not definitive in this regard. The recent descriptions of antibodies specific for different members of the trk family (Rush et al., 1992; Smith-Swintosky and Mattson, 1992; Spoerri et al., 1992; Tassone et al., 1992) should allow colocalization of $t r k$ expression with antibody markers and retrograde tracing to characterize further the functional classes of DRG neurons that express different neurotrophin receptors.

\section{Note added in proof}

Since acceptance of this article, another article dealing with expression of neurotrophin receptor genes in DRGs has appeared: Ernfors et al. (1993).

\section{References}

Allendoerfer KL, Cabelli RJ, Escandon E, Nikolics K, Shatz CJ (1992) Developmental regulation of neurotrophic factors receptors in the mammalian visual system. Soc Neurosci Abstr 18:228.

Altman J, Bayer SA (1984) The development of the rat spinal cord. Berlin: Springer.

Berkemeier I.R, Wilslow JW, Kaplan DR, Nikolics K, Goeddel DV, Rosenthal A (1991) Neurotrophin-5: a novel neurotrophic factor that activates trk and $t r k \mathrm{~B}$. Neuron 7:857-866.

Bothwell M (1991) Keeping track of neurotrophin receptors. Cell 65: 915-918.

Brown AG (1981) Organization in the spinal cord. New York: Springer.

Carroll SL, Silos-Santiago I, Frese SE, Ruit KG, Milbrandt J, Snider WD (1992) Dorsal root ganglia neurons expressing $t r k$ are selectively sensitive to NGF deprivation in utero. Neuron 9:779-788.

Cordón-Cardo C, Tapley P, Jing S, Nanduri V, O'Rourke E, Lamballe F, Kovary K, Klein R, Jones KR, Reichardt LF, Barbacid M (1991) The $t r k$ tyrosine protein kinase mediates the mitogenic properties of nerve growth factor and neurotrophin-3. Cell 66:173-183.

Davies AM, Thoenen H, Barde YA (1986) The response of chick sensory neurons to brain-derived neurotrophic factor. J Neurosci 6:1897-1904.
Davies AM, Bandtlow C, Heumann R, Korsehing S, Rohrer H, Theonen $H$ (1987) Timing and site of nerve growth factor synthesis in developing skin in relation to innervation and expression of the receptor. Nature 326:353-358.

Ernfors P, Persson H (1991) Developmentally regulated expression of HDNF/NT-3 mRNA in rat spinal cord motor neurons and expression of BDNF mRNA in embryonic dorsal root ganglion. Eur $J$ Neurosci 3:953-961.

Ernfors P, Merlio J-P, Persson H (1992) Cells expressing mRNA for neurotrophins and their receptors during embryonic rat development. Eur J Neurosci 4:1140-1158.

Ernfors P, Rosario CM, Merlio J-P, Grant G, Aldskogius H, Persson $H$ (1993) Expression of mRNAs for neurotrophin receptors in the dorsal root ganglion and spinal cord during development and following peripheral or central axotomy. Mol Brain Res 17:217-223.

Fitzgerald MJT (1967) Perinatal changes in epidermal innervation in rat and mouse. J Comp Neurol 126:37-42.

Fitzgerald M (1987) Prenatal growth of fine diameter primary afferents into the rat spinal cord: a transganglionic tracer study. J Comp Neurol 261:98-104.

Gorin PD, Johnson EM (1979) Experimental autoimmune model of nerve growth factor deprivation: effects on developing peripheral sympathetic and sensory neurons. Proc Natl Acad Sci USA 76:53825386.

Hamburger V, Brunso-Bechtold JK, Yip JW (1981) Neuronal death in the spinal ganglia of the chick embryo and its reduction by nerve growth factor. J Neurosci 1:60-71.

Hohn A, Leibrook J, Bailey K, Barde YA (1990) Identification and characterization of a novel member of the nerve growth factor/brain derived neurotrophic factor family. Nature 344:339-341.

Hökfelt T, Kellerth JO, Nilsson G, Pernow B (1975) Substance P: localization in the central nervous system and in some primary sensory neurons. Science 190:889-890.

Hory-Lee F, Russell M, Lindsay RM, Frank E (1993) Neurotrophin 3 supports the survival of developing muscle sensory neurons in culture. Proc Natl Acad Sci USA 90:2613-2617.

Hunt SP, Mantyh PW, Priestly JV (1992) The organization of biochemically characterized sensory neurons. In: Sensory neurons (Scott SA, ed), pp 60-76. New York: Oxford UP.

Ip N, Stitt TN, Tapley P, Klein R, Greene LA, Barbacid N, Yancopoulos GD (1993) Similarities and differences in the way neurotrophins interact with the trk receptors in neuronal and nonneuronal cells. Neuron 10:137-149.

Jacobson M (1991) Developmental neurobiology. New York: Plenum.

Jessell TM, Dodd J (1986) Neurotransmitters and differentiation antigens in subsets of sensory neurons projecting to the spinal dorsal horn. In: Neuropeptides in neurologic and psychiatric disease (Martin JB, Barchas JD, eds), pp 113-122. New York: Raven.

Johnson EM Jr, Gorin PD, Brandeis LD, Pearson J (1980) Dorsal root ganglion neurons are destroyed by exposure in utero to maternal antibody to nerve growth factor. Science 219:916-918.

Johnson EM Jr, Osborne PA, Rydel RE, Schmidt RE, Pearson J (1983) Characterization of the effects of autoimmune nerve growth factor deprivation in the developing guinea-pig. Neuroscience 8:631-642.

Johnson EM Jr, Rich KM, Yip HK (1986) The role of NGF in sensory neurons in vivo. Trends Neurosci 9:33-37.

Kaplan DR, Martín-Zanca D, Parada LF (1991a) Tyrosine phosphorylation and tyrosine kinase activity of the trk proto-oncogene product induced by NGF. Nature 350:158-160.

Kaplan DR, Hempstead BL, Martin-Zanca D, Chao MV, Parada LF (1991b) The $t r k$ proto-oncogene product: a signal transducing receptor for nerve growth factor. Science 252:554-558.

Kessler JA, Black IB (1980) Nerve growth factor stimulates the development of substance P in sensory ganglia. Proc Natl Acad Sci USA 77:649-652.

Klein R, Parada LF, Coulier F, Barbacid M (1989) trkB, a novel tyrosine protein kinase receptor expressed during mouse neural development. EMBO J 8:3701-3709.

Klein R, Conway D, Parada LF, Barbacid M (1990) The $t r k$ B tyrosine kinase gene codes for a second neurogenic receptor that lacks the catalytic kinase domain. Cell 61:647-656.

Klein R, Jing S, Nanduri V, O'Rourke E, Barbacid M (1991) The trk proto-oncogene encodes a receptor for nerve growth factor. Cell 65 : $189-197$.

Knyihar-Csillik E, Csillik B (1981) Histochemistry of the primary nociceptive neuron. J Histochem Cytochem 14:1-137. 
Lamballe F, Klein R, Barbacid M (1991) trkC, a new member of the trk family of tyrosine protein kinases, is a receptor for neurotrophin3. Cell 66:967-979.

Lawson SN (1992) Morphological and biochemical cell types of sensory neurons. In: Sensory neurons (Scott SA, ed), pp 27-59. New York: Oxford UP.

Lawson SN, Waddell PJ (1991) Soma neurofilament immunoreactivity is related to cell size and fiber conduction velocity in rat primary sensory neurones. J Physiol (Lond) 435:41-63.

Lawson SN, Caddy KWT, Biscoe TJ (1974) Development of rat dorsal root ganglion neurones. Studies of cell birthdays and changes in mean cell diameter. Cell Tissue Res 153:399-413.

Leibrock J, Lottspeich F, Hohn A, Hofer M, Hengerer B, Masiakowski $\mathrm{P}$, Thoenen H, Barde Y-A (1989) Molecular cloning and expression of brain-derived neurotrophic factor. Nature 341:149-152.

Lewin GR, Ritter AM, Mendel LM (1992) On the role of nerve growth factor in the development of myelinated nociceptors. J Neurosci 12: $1896-1905$

Lindsay RM, Thoenen H, Barde YA (1985) Placode and neural crestderived sensory neurons are responsive at early developmental stages to brain-derived neurotrophic factor. Dev Biol 112:319-328.

Maisonpierre PC, Belluscio L, Squinto S, Ip NY, Firth ME, Lindsay RM, Yancopoulos G (1990) Neurotrophin-3: a neurotrophic factor related to NGF and BDNF. Science 247:1446-1451.

Martin-Zanca D, Barbacid M, Parada LF (1990) Expression of the $t r k$ proto-oncogene is restricted to the sensory cranial and spinal ganglia of neural crest origin in mouse development. Genes Dev 4:638-694.

McCarthy PW, Lawson SN (1989) Cell type and conduction velocity of rat primary sensory neurons with substance P-like immunoreactivity. Neuroscience 28:745-753.

McNeil DL, Westlund KN, Coggeshall RE (1989) Peptide immunoreactivity of unmyelinated primary afferent axons in rat lumbar dorsal roots. J Histochem Cytochem 37:1047-1052.

Merlio J-P, Ernfors P, Jaber M, Persson H (1992) Molecular cloning of rat $t r k \mathrm{C}$ and distribution of cclls cxpressing messenger RNAs for members of the trk family in the rat central nervous system. Neuroscience 51:513-532.

Middlemas DS, Lindberg RA, Hunter T (1991) $t r k B$, a neural receptor protein-tyrosine kinase: evidence for a full-length and two truncated receptors. Mol Cell Biol 11:143-153.

Miyata Y, Kashihara Y, Homma S, Kuno M (1986) Effects of nerve growth factor on the survival and synaptic function of Ia sensory neurons axotomized in neonatal rats. I Neurosci 6:2012-2018.

Nagy JI, Hunt SP (1982) Fluoride-resistant acid phosphatase containing neurons in dorsal root ganglia are separate from those containing substance $\mathrm{P}$ or somatostatin. Neuroscience 7:89-97.

Otten U, Goedert M, Mayer N, Lembeck F (1980) Requirement of nerve growth factor for development of substance P-containing sensory neurons. Nature 287:158-159.

Perl ER (1992) Function of dorsal root ganglion neurons: an overview. In: Sensory neurons (Scott SA, ed), pp 3-23. New York: Oxford UP.

Reynolds ML, Fitzgerald M, Benowitz LI (1991) GAP-43 expression in developing cutaneous and muscle nerves in the rat hindlimb. Neuroscience 41:201-211.

Ritter AM, Lewin GR, Kremer NE, Mendell LM (1991) Requirement for nerve growth factor in the development of myelinated nociceptors in vivo. Nature 350:500-502

Ruit KG, Elliott JL, Osborne PA, Yan Q, Snider WD (1992) Selective dependence of mammalian dorsal root ganglion neurons on nerve growth factor during embryonic development. Neuron 8:573-587.

Rush RA, Zhou XF, Parada L (1992) Distribution of trkB tyrosine kinase immunoreactivity in the rat central nervous system. Soc Neurosci Abstr 18:227.

Schecterson LC, Bothwell M (1992) Novel roles for neurotrophins are suggested by BDNF and NT-3 mRNA expression in developing neurons. Neuron 9:449-463.

Scott SA (1992) The development of peripheral sensory innervation patterns. In: Sensory neurons (Scott SA, ed), pp 242-263. New York: Oxford UP.

Shimamura K, Takahashi T, Takeichi M (1992) E-cadherin expression in a particular subset of sensory neurons. Dev Biol 152:242-254.
Sieber-Blum M (1991) Role of the neurotrophic factors BDNF and NGF in the commitment of pluripotent neural crest cells. Neuron 6:949-955.

Silverman JD, Knger I (1988) Acid phosphatase as a selective marker for a class of small sensory ganglion cells in several mammalian species: spinal cord distribution, histochemical properties, and relation to fluoride-resistant acid phosphatase (FRAP) of rodents. Somatosens Res 5:219-246.

Skofitsch G, Jacobowitz DM (1985) Calcitonin gene-related peptide: detailed immunocytochemical distribution in the central nervous system. Peptides 6:721-745.

Smith CL (1983) The development and postnatal organization of primary afferent projections to the rat thoracic spinal cord. J Comp Neurol 220:29-43.

Smith-Swintosky VL, Mattson MP (1992) Evidence for the expression of functional low affinity and trkA NGF receptors in cultured hippocampal neurons. Soc Neurosci Abstr 18:951.

Snider WD, Zhang L, Yusoof S, Gorukanti N, Tsering C (1992) Interaction between dorsal root axons and their target motor neurons in developing mammalian spinal cord. $\mathbf{J}$ Neurosci 12:3494-3508.

Soppet D, Escandon E, Maragos J, Middlemas DS, Reid SW, Blair J, Burton LE, Stanton BR, Kaplan DR, Hunter T, Nikolics K, Parada LF (1991) The neurotrophic factors brain-derived neurotrophic factor and neurotrophin-3 are ligands for the $t r k \mathbf{B}$ tyrosine kinase receptor. Cell 65:895-903.

Spoerri P, Petrelli R, Dal Toso R, Skaper SE (1992) Immuno-ultrastructural localization of low- and high-affinity NGF receptors on neural cells. Soc Neurosci Abstr 18:1100.

Squinto SP, Stitt TN, Aldrich TH, Davis S, Bianco SM, Radziejewski C, Glass DJ, Masiakowski P, Furth ME, Valenzuela DM, DiStefano PS, Yancopoulos GD (1991) trkB encodes a functional receptor for brain-derived neurotrophic factor and neurotrophin-3 but not nerve growth factor. Cell 65:885-893.

Streit WJ, Schulte BA, Balentine JB, Spicer SS (1985) Histochemical localization of galactose containing glycoconjugates in sensory neurons and their processes in the central and peripheral nervous system of the rat. J Histochem Cytochem 33:1042-1052.

Tassone JI, Yokoyama M, Black IB, Dryfus CF (1992) Colocalization of NGF binding sites to trk and p75 expressing cells in basal forebrain cultures. Soc Neurosci Abstr 18:948.

Tecott LH, Eberwine JH, Barchas JD, Valentino KL (1987) Methodological considerations in the utilization of in situ hybridization In: In situ hybridization. Applications to neurobiology (Valentino KL Eberwine JH, Barchas JD, eds), pp 3-24. New York: Oxford UP.

Verge VMK, Merlio JP, Grondin J, Ernfors P, Persson H, Riopelle RJ, Hökfelt T, Richardson PM (1992) Colocalization of NGF binding sites, trk mRNA, and low-affinity NGF receptor mRNA in primary sensory neurons: response to injury and infusion of NGF. J Neurosci 12:4011-4022.

Wanaka A, Johnson EM Jr, Mildbrandt J (1990) Localization of FGF receptor mRNA in the rat adult central nervous system by in situ hybridization. Neuron 5:267-281.

Wiesenfeld-Hallin Z, Hökfelt T, Lundberg JM, Forssmann WG, Reineke M, Tschopp FA, Fisher JA (1984) Immunoreactive calcitonin gene-related peptide and substance $P$ co-exist in sensory neurons to the spinal cord and interact in spinal behavioral responses of the rat. Neurosci Lett 52:199-204.

Willis WD, Coggeshall RE (1991) Sensory mechanisms of the spinal cord. New York: Plenum.

Wright EM, Vogel KS, Davics AM (1992) Ncurotrophic factors promote the maturation of developing sensory neurons before they become dependent on these factors for survival. Neuron 9:139-150.

Wyatt S, Parada L, Meakin SO, Davies A (1992) Regulation of p75NGF and pl40trk expression in developing sensory neurons in relation with innervation and changes in neurotrophic factor responsiveness. Soc Neurosci Abstr 18:1290.

Yeh HJ, Ruit KG, Wang YX, Parks WC, Snider WD, Deuel TF (1991) PDGF A-chain gene is expressed by mammalian neurons during development and in maturity. Cell 64:209-216. 